\title{
The observed incidence of anaphylaxis and serum sickness in patients receiving omalizumab in a tertiary allergy and asthma clinic in Canada
}

\author{
Megan MacRae ${ }^{1 *}$, Stephanie Santucci ${ }^{1}$, Jacob Karsh², William H. Yang ${ }^{1,2}$ \\ From Canadian Society of Allergy and Clinical Immunology Annual Scientific Meeting 2014 \\ Ottawa, ON, Canada. 23-26 October 2014
}

\section{Background}

In a post-marketing analysis last updated in July 2007, the FDA reported that an estimated $0.2 \%$ of patients suffered treatment related anaphylaxis and rare incidence of serum sickness. To substantiate this, the occurrence of treatment related anaphylaxis and serum sickness in our large Canadian allergy and asthma tertiary clinic was assessed.

\section{Methods}

A retrospective chart review of our database of omalizumab administration between 1998 and June 2014 was performed.

\section{Results}

During clinical trials and with our post market experience, between 1998 and June 2014, over 21,000 injections of omalizumab to more than 250 patients were administered and no cases of anaphylaxis or serum sickness like symptoms were observed.

\section{Conclusion}

Meticulous care was taken by our omalizumab administration clinic to ensure optimal safety based on the emphasized warnings of anaphylaxis, as well as, the indicated warnings and precautions for serum sickness. Data collected in this analysis observed no cases of anaphylaxis or serum sickness like symptoms in the treatment of over 250 patients, during a period of 15.5 years, who combined received 21,000 injections of omalizumab thus confirming the low incidence of both anaphylaxis and serum sickness.

${ }^{1}$ Allergy and Asthma Research Centre, Ottawa, ON, Canada

Full list of author information is available at the end of the article

\author{
Authors' details \\ ${ }^{1}$ Allergy and Asthma Research Centre, Ottawa, ON, Canada. ${ }^{2}$ University of
}

Ottawa Medical School, Ottawa, ON, Canada.

Published: 18 December 2014

doi:10.1186/1710-1492-10-S2-A28

Cite this article as: MacRae et al:: The observed incidence of anaphylaxis and serum sickness in patients receiving omalizumab in a tertiary allergy and asthma clinic in Canada. Allergy, Asthma and Clinical Immunology 2014 10(Suppl 2):A28.
Submit your next manuscript to BioMed Central and take full advantage of:

- Convenient online submission

- Thorough peer review

- No space constraints or color figure charges

- Immediate publication on acceptance

- Inclusion in PubMed, CAS, Scopus and Google Scholar

- Research which is freely available for redistribution
() Biomed Central 